Assessment of Heavy Metals Pollution in Water and Sediments and Polychaetes in Sinop Shores of the Black Sea

\author{
Levent BAT ${ }^{\wedge}$ (D), Fatih ŞAHIN ${ }^{2}$, Ayşah ÖZTEKİN ${ }^{3}$ (D) \\ 1,2,3 Department of Hydrobiology, Fisheries Faculty, Sinop University, 57000, Sinop, \\ ${ }^{1}$ https://orcid.org/0000-0002-2289-6691, ${ }^{2}$ https://orcid.org/0000-0003-0605-2672, ${ }^{3}$ https://orcid.org/0000-0002-3726-7134 \\ $凶$ : leventbat@gmail.com
}

\section{ABSTRACT}

In this study four Polychaetes species namely Capitella capitata, Nereis zonata, Platynereis dumerilii and Perinereis cultrifera were selected to evaluate metal pollution in Karakum shores of Sinop Peninsula in the southern Black Sea. The $\mathrm{Hg}, \mathrm{Cd}, \mathrm{Pb}, \mathrm{Cu}$ and $\mathrm{Zn}$ amounts in water, sediment as well as their existence in Polychaetes were studied to appraise the anthropogenic impact on their environment. Metals concentrations in water were found in the following order: $\mathrm{Zn}>\mathrm{Cu}>\mathrm{Pb}>\mathrm{Cd}>\mathrm{Hg}$, whereas the order of abundance of these metals in sediments were as follow $\mathrm{Zn}>\mathrm{Cu}>\mathrm{Pb}$ $>\mathrm{Hg}>\mathrm{Cd}$. There were no differences in heavy metal levels in sediment between seasons. The concentration of metals analysed in the Polychaete species showed same pattern. Zn showed the highest concentration in all species followed by $\mathrm{Cu}$. The results showed that the heavy metal levels in $C$. capitata were much higher than those in $N$. zonata, $P$. dumerilii and $P$. cultrifera.

\section{Research Article}

$\begin{array}{ll}\text { Article History } & \\ \text { Received } & : 05.03 .2019 \\ \text { Accepted } & : 09.05 .2019\end{array}$

\section{Keywords}

Polychaetes,

heavy metals,

Black Sea,

bio-indicator

C. capitata

\title{
Karadeniz'in Sinop Kıylarında Su, Sediman ve Poliketlerde Ağır Metal Kirliliğinin Değerlendirilmesi
}

\section{ÖZET}

$\mathrm{Bu}$ çalışmada, Karadeniz'in güneyinde Sinop Yarımadası'nın Karakum kıyılarında metal kirliliğini değerlendirmek için Capitella capitata, Nereis zonata, Platynereis dumerilii ve Perinereis cultrifera olmak üzere dört Poliket türü seçilmiştir. Suda, sedimanda ve Poliketlerde $\mathrm{Hg}, \mathrm{Cd}, \mathrm{Pb}, \mathrm{Cu}$ ve $\mathrm{Zn}$ miktarları tespit edilerek bunların çevreleri üzerindeki antropojenik etki değerlendirilmiştir. Sudaki metal konsantrasyonları sirasiyla: $\mathrm{Zn}>\mathrm{Cu}>\mathrm{Pb}>\mathrm{Cd}>\mathrm{Hg}$ olarak, bu metallerin sedimandaki bolluğu ise sirasıyla: $\mathrm{Zn}>\mathrm{Cu}>\mathrm{Pb}>\mathrm{Hg}>\mathrm{Cd}$ olarak bulunmuştur. Sedimandaki ağır metal seviyesinde mevsimler arasında fark bulunamamıştır. Poliket türlerinde analiz edilen metallerin konsantrasyonu da aynı düzeni göstermiştir. Zn tüm türlerde en yüksek konsantrasyonda bulunurken bunu $\mathrm{Cu}$ takip etmiştir. Sonuçlar, C. capitata türündeki ağır metal seviyelerinin $N$. zonata, $P$. dumerilii ve $P$. cultrifera türlerindeki birikimlerinden daha çok olduğunu göstermiştir.

\section{Araştırma Makalesi}

Makale Tarihçesi

Geliş Tarihi : :05.03.2019

Kabul Tarihi : 09.05.2019

Anahtar Kelimeler
Poliketler
Ağır metaller
Karadeniz
Biyo-indikatör
C. capitata

To Cite : Bat L, Şahin F, Öztekin A 2019. Assessment of heavy metals pollution in water and sediments and Polychaetes in Sinop shores of the Black Sea. KSU J. Agric Nat 22(5): 806-816. DOI: ksutarimdoga.v22i45606.535882

\section{INTRODUCTION}

Pollution of the Black Sea by chemicals such as heavy metals has been recognized as one of the major factors threat to the survival of biota especially benthic invertebrates (Bat, 2005; Bat and Arici, 2018).

The Black Sea is the most important natural resource for biodiversity in Turkey (Bat et al., 2011). It still continuous the main source of fish and other seafood in the country for a long time. However, the Black Sea was subjected to a drastic pollution during the last few decades due to industrial, agricultural and sewage effluents and runoffs from major rivers along their coasts (Bat et al., 2018). These cause the accumulation of large quantities of contaminants such as heavy metals in water bodies and sediments.

Metal ions can be included into food-chains and accumulated in organisms to an amount that affects their physiological state. One of the most effective contaminants is the heavy metals which have serious environmental impact on biota. Heavy metals such as 
$\mathrm{Cu}$ and $\mathrm{Zn}$ play biochemical role in the life processes of the biota, therefore, they are essential in the aquatic environment in low levels. Whereas non-essential heavy metals like $\mathrm{Hg}, \mathrm{Cd}$ and $\mathrm{Pb}$ have no any beneficial role in biota even at trace amounts.

What do the heavy metals harmful, is not their main characteristics, on the other hand the amounts that may appear, and most principal, the kind of form given on specific environment, its threat is potentiated by not existing chemically or biologically decomposed, once released metals can stay in the environment for hundreds of years, and therefore, they are accumulated into aquatic organisms (Noreña et al., 2012).

Undoubtedly, aquatic organisms especially are the natural habitat of the water, so it is difficult for them to escape from the toxic effects of heavy metals. Suspended sediments adsorb contaminants from the water, hence reducing their levels in the surrounding water. In general, it is considered sediments are deposited on the bottom of sea and are the last destination of both natural and anthropogenic components produced or derived to the environment (Bat and Özkan, 2015). Especially benthic organisms exposed to heavy metals in contaminated waters and sediments. Accumulation of heavy metals in aquatic organisms can take place either by accumulation from the environment, such as water or sediment, or by bioaccumulation from the foods. Consequently, managing the origins of contamination of water and sediment in the marine ecosystem is the solution for aquatic organisms' protection. Benthic organisms have been widely used in biomonitoring of the aquatic environment where they live and assessment of safe levels of heavy metals (Bat, 2005; Bat and Arici, 2018). Therefore, sediment quality is a good indicator of pollution in water column, where it inclines to be accumulated in the heavy metals.

Various studies have been done on heavy metals accumulation in biota in the Black Sea coasts (Bat et al., 2009; Bat, 2017; Bat and Arici, 2018). Some heavy metals concentrations have been determined in surficial sediments by Bat et al. (2015), Bat and Özkan (2015) and in water (Arici and Bat, 2017) of the Black Sea.

Thus, the present work aimed to investigate the accumulation of $\mathrm{Hg}, \mathrm{Cd}, \mathrm{Pb}, \mathrm{Cu}$ and $\mathrm{Zn}$ in water, sediment and Polychaetes in Sinop shores of the southern Black Sea.

\section{MATERIALS AND METHODS}

\section{Sampling Area}

Karakum region was chosen as sampling area. It is located on the southern coast of Sinop Peninsula in Central Black Sea region of Turkey (Figure 1). Karakum is located $2 \mathrm{~km}$ apart from the city center and takes its name from the fine black sand of volcanic structure. Its average depth is around $30 \mathrm{~m}$ and deepening with a smooth slope from the beach (5-30 $\mathrm{m})$. There are large rocks up to $12 \mathrm{~m}$ depth from the coast where covered with mussel beds brown and green algae. Coastal currents are very strong for this region. There is no significant pollution in this area. It is used extensively as a beach during the summer months.

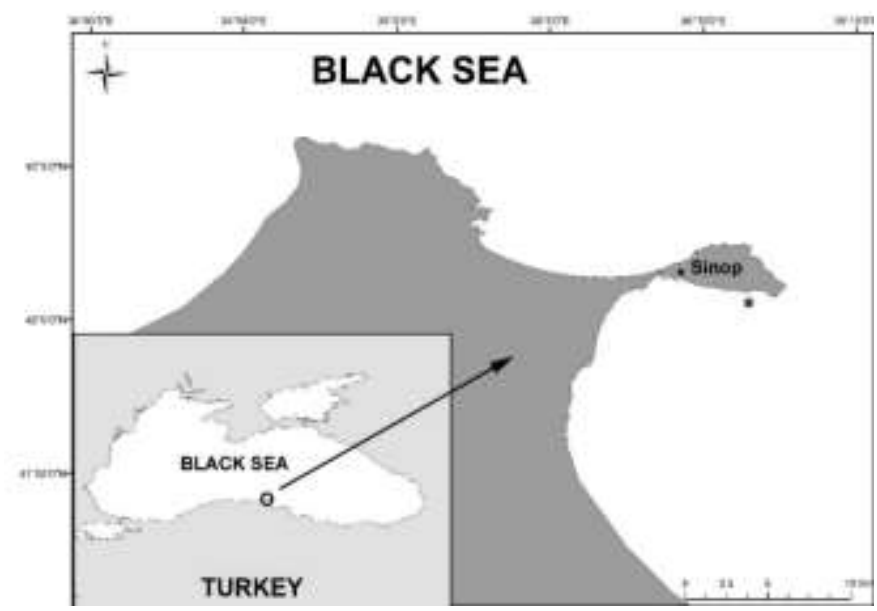

Figure 1. Sampling area.

\section{Sampling and Analysis Regime}

\section{Polychaetes species}

In this study four Polychaetes species namely Capitella capitata (Fabricius, 1780), Nereis zonata Malmgren, 1867, Platynereis dumerilii (Audouin and Edwards, 1833) and Perinereis cultrifera (Grube, 1840) were selected to evaluate metal pollution in Karakum shores of Sinop Peninsula in the southern Black Sea. They were collected by SCUBA-diving seasonally in the year of 2016 from either bottoms with rocks and alga or in muddy sand and fine sand on the middle and lower shore. They were available in all seasons during the sampling period, but their densities fluctuated with environmental conditions. However, a sufficient number of individuals and necessary amounts of tissue were obtained for metal analyses. After collection, the animals were separated by species and washed with seawater to remove any debris on them and put each species in different tanks with aerated clean seawater for 48 hours to empty gut contents. Each species was kept separately in cleaned polyethylene bags untill heavy metal analyses.

\section{Water samples}

Dissolved oxygen, water temperature, $\mathrm{pH}$, conductivity and salinity values of seawater were measured in situ by using an YSI 6600 CTD probe.

The samples were mixed in a plastic bucket and a sample of 1 liter was placed in a polyethylene bottle, kept refrigerated and transferred cold to the laboratory 
for metal analysis.

In determining the total amount of suspended solids (TSS), unfiltered seawater samples were filtered with tared filter paper and $0.45 \mu \mathrm{m}$ Millipore filter system. After filtration, the filter paper was dried in the oven at 103 to $105^{\circ} \mathrm{C}$ for minimum of an hour, cool dish in desiccator to balance temperature and weighed. The suspended solids were determined by the weighting of the filter papers after filtration and drying.

\section{Sediment Samples}

Sediment samples were collected as three replicates using PVC cores of 10 centimetres in length with a diameter of $4 \mathrm{~cm}$ by divers and stored at $-21^{\circ} \mathrm{C}$ for granulometry, organic matter, water content, $\mathrm{pH}$ and oxidation-reduction potential analyses carried out in the laboratory. The sediments samples were placed in cleaned polyethylene bags and chilled on ice box for transporting to the laboratory.

Granulometric analysis was performed following Buchanan (1984) and sediment types were determined according to Wentworth's (1922) scale. It was made by the sieve analysis method which is the most common fastest method with the best result. Approximately 500 $\mathrm{g}$ sediment was weighed and dried in oven at $105^{\circ} \mathrm{C}$ for 48 hours. The dried sediment samples were passed through six mesh sieves with $2 \mathrm{~mm}, 1 \mathrm{~mm}, 500 \mu \mathrm{m}, 125$ $\mu \mathrm{m}, 100 \mu \mathrm{m}$ and $63 \mu \mathrm{m}$ sizes. Samples of sediment on each sieve are weighed and particle sizes are classified according to \% weight values (Wentworth, 1922).

Sediment samples for total organic carbon analysis were dried at $105^{\circ} \mathrm{C}$ for $24 \mathrm{~h}$. Five grams of dried sample were then treated with hydrochloric acid vapour overnight in a desiccating jar to convert any calcium carbonates to chlorides. Samples were then placed in a muffle furnace at $600^{\circ} \mathrm{C}$ for 4 hours. The loss ignition was taken as the organic carbon content of the sediment (Buchanan, 1984).

In order to determine the water content, dry weight was weighed after drying them for 2 days. After cooling, water content (\%) was calculated from weight differences. For the $\mathrm{pH}$ analysis, 1: 2.5 percent pure water were added to the sediment samples taken in a certain amount and the samples were thoroughly mixed in the water. After 30 min sediments were expected to settle in water, $\mathrm{pH}$ was measured by $\mathrm{pH}$ mete. Oxidation-reduction (Eh) values were measured with Portable redox-meter.

\section{Heavy Metal Analysis}

In water samples, heavy metals were extracted with 1 ml of concentrated ultrapure $\mathrm{HNO}_{3}$ for each 250cc water sample, then put in polyethylene bottles and finally preserved in a refrigerator for metal analysis (Arici and Bat, 2017). In the laboratory, the sediment samples were dried at $105{ }^{\circ} \mathrm{C}$ for 24 hours and about
$1.0 \mathrm{~g}$ of the dried sediment were digested with Seawater Sediment HPR-EN-33 methodology (Milestone Systems, Start D 260) and preserved in a refrigerator until metal analysis.

Whole soft tissues of Polychaetes species were used for heavy metal analysis. Homogeneous samples of each biological sample for metal analysis were taken from each species, and were rinsed with deionized water. The samples digested with Suprapur ${ }^{\circledR} \mathrm{HNO}_{3}$ (using a microwave digestion system (Milestone Systems, Start D 260). The accuracy of the analytical method in the current work was assessed using the Standard Reference Materials (SRM) 2702 (marine sediment) from National Institute of Standards and Technology (NIST) and Certified Reference Material TORT-2 (lobster hepatopancreas) from National Research Council Canada (NRC). Results of the measurements were in good agreement between the certified and the analytical values, together with the Relative Standard Deviation (RSD) percentage which always in range of $5 \%$. Selected metals ( $\mathrm{Hg}, \mathrm{Cd}, \mathrm{Pb}, \mathrm{Cu}$ and $\mathrm{Zn}$ ) in all samples were determined with ICP-MS (Agilent Technologies, 7700X), used three replicates and results of mean concentrations were detected as ppb in water and $\mathrm{mg} / \mathrm{kg}$ dry wt. in sediments and biota samples. The sensitivity of the method was determined according to the detection limits established for the spectrometer, which were $<0.001 \mu \mathrm{g} / \mathrm{L}$ for $\mathrm{Pb}$ and $\mathrm{Cd},<0.01 \mathrm{Zn}$ and $\mathrm{Hg}$ and $<0.0001 \mu \mathrm{g} / \mathrm{L}$ for $\mathrm{Cu}$.

\section{Statistical Analysis}

Statistical analyses of data were carried out using SPSS version 21 software. One-way ANOVA and Duncan multiple range test were applied to calculate the significant differences in the concentrations of different studied metals with respect to different seasons at $\mathrm{P} \leq 0.05$ level (Zar, 1984).

\section{RESULTS}

The accuracy of the method was evaluated by repeated analyses of compositionally appropriate Certified Reference Materials; NIST -SRM 2702 (marine sediment) and NRC- TORT-2 (lobster hepatopancreas) under the same experimental conditions as the samples. The accuracy of the measurements, in terms of the relative deviation from the certified values was all within $\pm 5 \%$. From this, it was realized that, the agreement between the certified values and the values obtained in this study was very good.

\section{Seawater Parameters}

During the study, dissolved oxygen were found between 5.31 and $6.28 \mathrm{mg} / \mathrm{L}$, and surface water temperatures ranged between 10.1 and $25.1^{\circ} \mathrm{C}$. Salinity ranged between 17.5 PSU and 17.8 PSU, pH was between 7.91 to 8.82 and conductivity ranged from 
28.26 to $29.2 \mathrm{mS} / \mathrm{cm}$. TSS values were found between 125 and $146 \mathrm{mg} / \mathrm{L}$. Results of water quality in Karakum shores of Sinop Peninsula in the Black Sea are shown in Table 1.

\section{Sediment Parameters}

Sediment types were determined according to Wentworth's (1922) scale and presented in Table 2. Data on organic carbon, water content, $\mathrm{pH}$ and redox values of sediment from Karakum shores of Sinop Peninsula in the Black Sea are given in Table 3.

\section{Heavy Metals in Water}

Metal concentrations in water at Karakum shores of Sinop Peninsula in the Black Sea are illustrated in
Figure 2. Metals concentrations in water were found in the following order: $\mathrm{Zn}>\mathrm{Cu}>\mathrm{Pb}>\mathrm{Cd}>\mathrm{Hg}$. $\mathrm{Hg}$ and $\mathrm{Cd}$ concentrations in seawater in Karakum coasts of Sinop province was not significantly different $(\mathrm{P}>0.05)$ by season. Other metals ( $\mathrm{Pb}, \mathrm{Cu}$ and $\mathrm{Zn}$ ) showed significant seasonal differences $(\mathrm{P}<0.05)$.

\section{Heavy Metals in Polychaete Species}

The levels of the heavy metals in the whole soft tissues of Polychaete species from study area were given in Figure 3. The concentration of metals analysed in the Polychaete species in decreasing order were $\mathrm{Zn}>\mathrm{Cu}>\mathrm{Pb}>\mathrm{Hg} \geq \mathrm{Cd}$. Studied heavy metal amounts were found to be significantly higher in $C$. capitata than those in other Polychaete species $(\mathrm{P}<0.05)$.

Table 1. Water quality of Karakum shores of Sinop Peninsula in the Black Sea

\begin{tabular}{lllll}
\hline Parameters & Spring & Summer & Autumn & Winter \\
\hline Dissolved oxygen $(\mathrm{mg} / \mathrm{L})$ & $5.84 \pm 0.1^{\mathrm{a}}$ & $5.31 \pm 0.1^{\mathrm{b}}$ & $5.67 \pm 0.1^{\mathrm{c}}$ & $6.28 \pm 0.1^{\mathrm{d}}$ \\
Temperature $\left({ }^{\circ} \mathrm{C}\right)$ & $19.2 \pm 0.1^{\mathrm{a}}$ & $25.1 \pm 0.2^{\mathrm{b}}$ & $13.7^{\mathrm{a}} \mathrm{2^{ \textrm {c } }}$ & $10.1^{\mathrm{a}} \pm .1^{\mathrm{d}}$ \\
pH & $8.79 \pm 0.1^{\mathrm{a}}$ & $8.82 \pm 0.1^{\mathrm{a}}$ & $7.95 \pm 0.1^{\mathrm{b}}$ & $7.91 \pm 0.1^{\mathrm{b}}$ \\
Conductivity $(\mathrm{mS} / \mathrm{cm})$ & $28.7 \pm 0.12^{\mathrm{a}}$ & $28.8 \pm 0.13^{\mathrm{a}}$ & $28.6 \pm 0.11^{\mathrm{a}}$ & $29.2 \pm 0.14^{\mathrm{a}}$ \\
Salinity (\%o) & $17.5 \pm 0.2^{\mathrm{a}}$ & $17.6 \pm 0.2^{\mathrm{a}}$ & $17.7 \pm 0.2^{\mathrm{a}}$ & $17.8 \pm 0.2^{\mathrm{a}}$ \\
TSS (mg/L) & $125 \pm 10^{\mathrm{a}}$ & $157 \pm 15^{\mathrm{b}}$ & $138 \pm 12^{\mathrm{c}}$ & $146 \pm 13^{\mathrm{b}, \mathrm{c}}$ \\
\hline
\end{tabular}

. a, b, c, $d=$ The same letters in each line indicate the values are not significantly different $(p>0.05)$.

Table 2. Sediment particle analysis

\begin{tabular}{|c|c|c|c|c|c|c|c|c|}
\hline \multirow{3}{*}{ Season } & \multicolumn{8}{|c|}{ Particle Size (\%) } \\
\hline & $>2$ & $>1$ & & $>1 / 2$ & $>1 / 4$ & $>1 / 8$ & $>1 / 16$ & $<1 / 16$ \\
\hline & $\begin{array}{l}\text { Very fine } \\
\text { gravel }\end{array}$ & $\begin{array}{l}\text { Very } \\
\text { sand }\end{array}$ & coarse & Coarse Sand & Medium sand & Fine sand & Very fine sand & Silt \\
\hline Spring & 1.14 & 9.55 & & 62.53 & 23.27 & 3.41 & 0.08 & 0.02 \\
\hline Summer & 0.61 & 7.97 & & 57.27 & 31.34 & 2.61 & 0.14 & 0.06 \\
\hline Autumn & 1.45 & 6.68 & & 69.94 & 19.93 & 1.87 & 0.09 & 0.04 \\
\hline Winter & 0.91 & 8.58 & & 73.76 & 15.17 & 1.45 & 0.11 & 0.02 \\
\hline
\end{tabular}

Table 3. Organic carbon, water content, $\mathrm{pH}$ and redox values of sediment in Karakum shores.

\begin{tabular}{lllll}
\hline Parameters & Spring & Summer & Autumn & Winter \\
\hline Organic carbon (\%) & $0.38 \pm 0.1^{\mathrm{a}}$ & $0.95 \pm 0.2^{\mathrm{b}}$ & $0.81 \pm 0.2^{\mathrm{c}}$ & $0.28 \pm 0.1^{\mathrm{d}}$ \\
Water content (\%) & $23.5 \pm 0.4^{\mathrm{a}}$ & $19.2 \pm 0.1^{\mathrm{b}}$ & $31.1^{\mathrm{a}} \pm 0.6^{\mathrm{c}}$ & $21.3 \pm 0.2^{\mathrm{a}}$ \\
pH & $8.3 \pm 0.1^{\mathrm{a}}$ & $8.7 \pm 0.1^{\mathrm{b}}$ & $8.9 \pm 0.1^{\mathrm{b}}$ & $7.9 \pm 0.1^{\mathrm{c}}$ \\
Redox (Eh, Mv) & $-118^{\mathrm{a}}$ & $-187^{\mathrm{b}}$ & $-162^{\mathrm{c}}$ & $-94^{\mathrm{d}}$ \\
\hline
\end{tabular}

$\mathrm{a}, \mathrm{b}, \mathrm{c}, \mathrm{d}=$ The same letters in each line indicate the values are not significantly different $(\mathrm{p}>0.05)$.
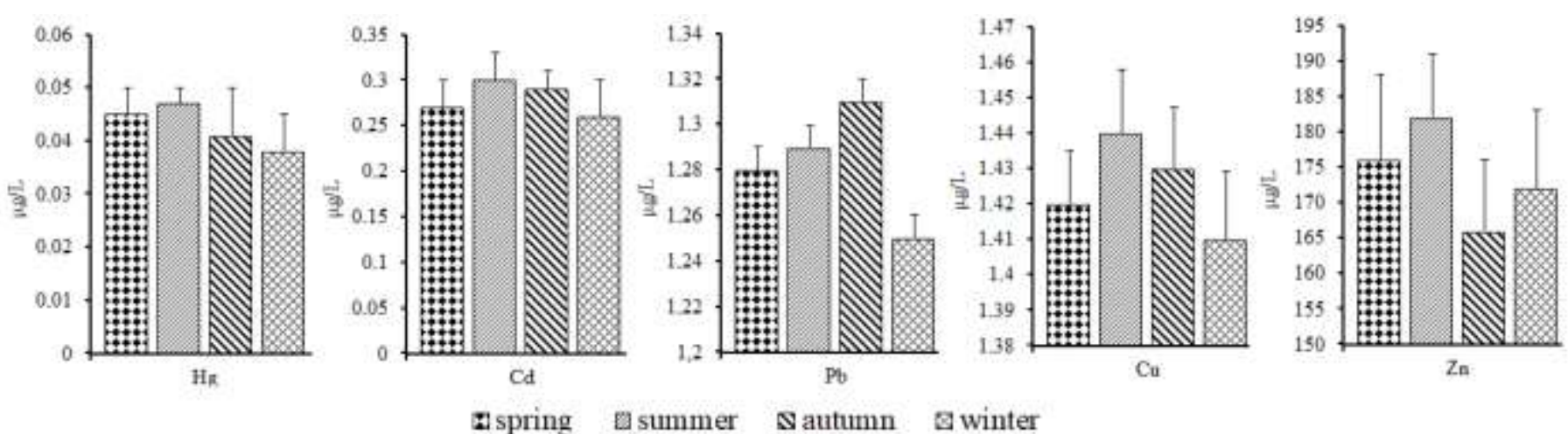

Figure 2. Heavy metal concentrations (mean $\pm \mathrm{SD}$ ) in water at Karakum shores 

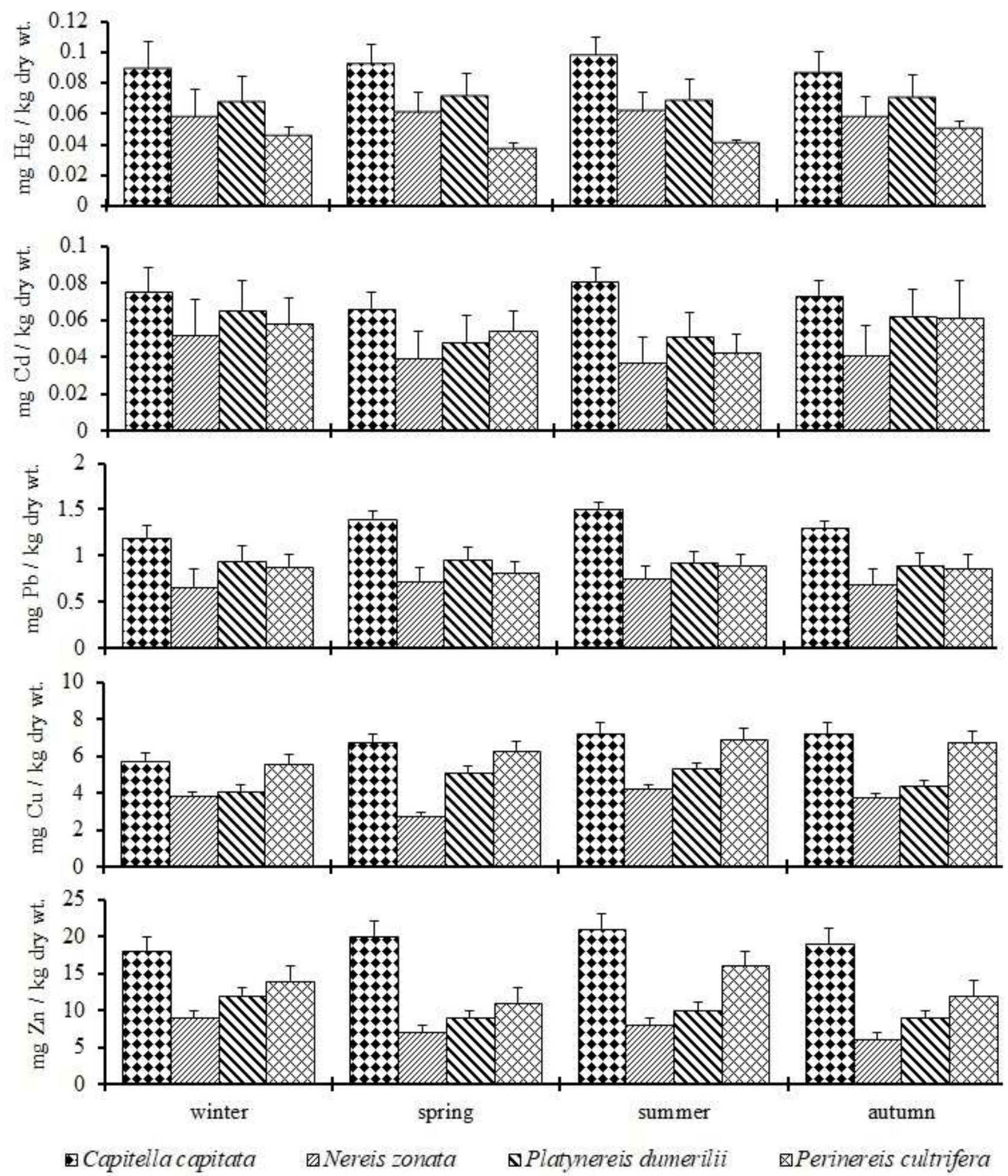

Figure 3. Heavy metal concentrations (mean \pm SD) in Polychaetes at Karakum shores

\section{Heavy Metals in Sediment}

The results obtained for the sediment analysis are shown in Figure 4. The order of abundance of these metals in sediments at Karakum shores of Sinop Peninsula in the Black Sea were as follow $\mathrm{Zn}>\mathrm{Cu}>$ $\mathrm{Pb}>\mathrm{Hg}>\mathrm{Cd}$. There was no differences in heavy metal levels in sediment between seasons $(\mathrm{P}>0.05)$.

\section{DISCUSSION}

As it is expected, the dissolved oxygen, temperature, $\mathrm{pH}$ and TSS were significantly different seasonally. However, all the conductivity and salinity values obtained at the various seasons did not differ significantly (Table 1). The difference in Karakum coastal water temperature between summer and winter was relatively high. 

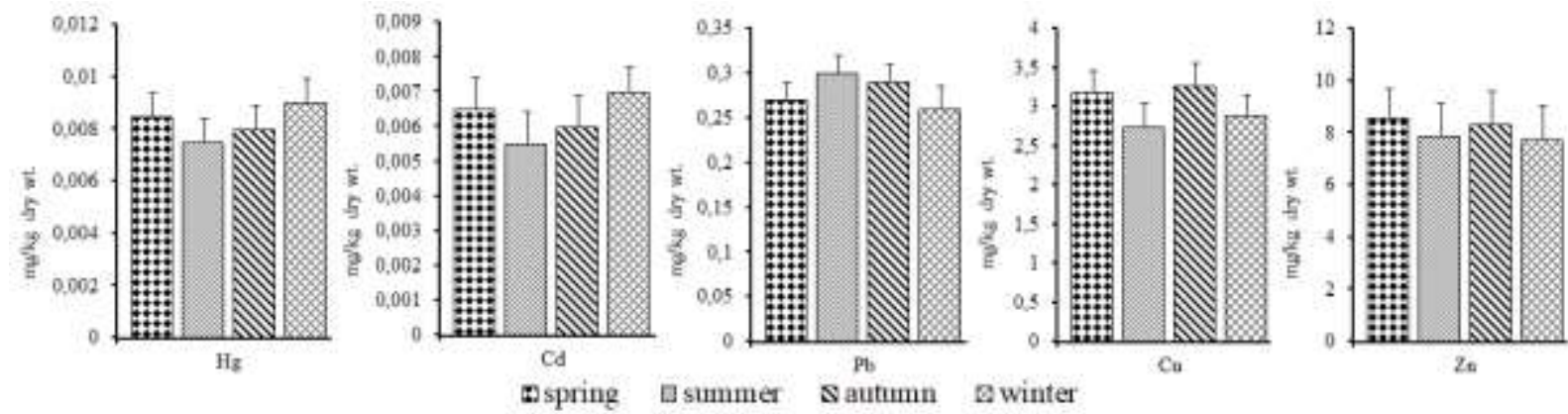

Figure 4. Heavy metal concentrations $($ mean $\pm \mathrm{SD})$ in sediment at Karakum shores

This suggests that conditions in the ambient environment could change abruptly from summer to winter and therefore might affect the physiology of the Polychaetes. Oxygen is essential to aquatic ecosystem, including those organisms responsible for the selfpurification processes in natural waters. The solubility of oxygen decreases as temperature and salinity increase. Amounts in unpolluted waters are generally close to, but less than $10 \mathrm{mg} \mathrm{l}^{-1}$. During the course of the study period dissolved oxygen concentrations ranged between minimum of $5.31 \pm 0.1 \mathrm{mg} / \mathrm{L}$ (summer) to maximum of $6.28 \pm 0.1 \mathrm{mg} / \mathrm{L}$ (winter).

The $\mathrm{pH}$ is a significant parameter in water quality assessment as it influences bio-chemical processes within a water body and all processes associated with water supply and treatment. In general, the $\mathrm{pH}$ of natural waters ranges between 6.0 and 8.5, although lower values can occur in dilute waters having higher concentration of dissolved organic substances, and higher values in eutrophic waters. The $\mathrm{pH}$ was found as $7.91 \pm 0.1$ (winter) and $8.82 \pm 0.1$ (summer).

Conductivity is a measure of the electric current carrying ability of water and is related to the concentration of dissolved ions present. Conductivity measurements can be used as a simple and effective means of monitoring temporal or spatial changes in salt concentrations such as those that occur in catchments undergoing salinization. The values of conductivity were recorded as $28.6 \pm 0.11 \mathrm{mS} / \mathrm{cm}$ (autumn) to $29.2 \pm 0.14 \mathrm{mS} / \mathrm{cm}$ (winter).

Total suspended solids are called residues obtained by filtration and drying of water samples. TSS values depend on various factors like rainfall and amount of surface runoffs and give an indication of the degree of dissolved substances. These substances, in natural waters, decreases the light transmittance causing the bottom to accumulate or directly damages the aquatic organisms. The observed TSS values were ranged from $125 \pm 10 \mathrm{mg} / \mathrm{L}$ (spring) to $157 \pm 15 \mathrm{mg} / \mathrm{L}$ (summer).

Water quality is very important for the survival of biota. All parameters measured is in accordance with the standards set by Turkish Official Gazette (Official Gazette of Republic of Turkey, 1983) and regulations (Turkish Environmental Regulations Water Pollution Control Regulation, 2004-2005). Results indicated that Sinop shores is under favourable condition for the survival of polychaete species. The differences in $\mathrm{Hg}$ and $\mathrm{Cd}$ levels were not significant seasonally $(\mathrm{P}>0.05)$.

However concentrations of $\mathrm{Pb}, \mathrm{Cu}$ and $\mathrm{Zn}$ in seawater varied $(\mathrm{P}<0.05)$. All the metals except $\mathrm{Pb}$ attained their maximum values in summer. Maximum $\mathrm{Pb}$ level was found in autumn attributing to the high amounts of sewage and touristic activities during summer.

Comparing the present mean results with previous studies in Karakum shores, all metal levels found in this study were generally lower than those found in the available studies on the other Black Sea coasts (Table $4)$.

Table 4. Comparison of heavy metals concentration $(\mu \mathrm{g} / \mathrm{L})$ in water of the Black Sea with previous studies.

\begin{tabular}{|c|c|c|c|c|c|c|}
\hline \multirow{2}{*}{ Location } & \multicolumn{5}{|l|}{ Metals } & \multirow{2}{*}{ References } \\
\hline & $\mathrm{Hg}$ & $\mathrm{Cd}$ & $\mathrm{Pb}$ & $\mathrm{Cu}$ & $\mathrm{Zn}$ & \\
\hline Sinop & 0.042 & 0.28 & 1.28 & 1.43 & 174 & This study \\
\hline Zonguldak & - & $0.29-1.71$ & $5.19-8.02$ & $2.84-7.73$ & $11.4-54.2$ & Coban et al. (2009) \\
\hline Çamburnu & - & 3.0 & ND & 19.5 & 6.5 & \\
\hline Rize (inner of harbor) & - & ND & 29.0 & 7.5 & 207.5 & \\
\hline Rize (out of harbor) & - & ND & $\mathrm{ND}$ & ND & 12.0 & _Cevik et al. (2008) \\
\hline Çayeli & - & ND & 17.5 & 9.0 & 6.0 & \\
\hline Hopa & - & $\mathrm{ND}$ & 39.0 & 20.5 & 81.5 & \\
\hline Sinop & $0.03-0.27$ & $0.32-0.64$ & $1.23-6.61$ & $1.39-17.56$ & $181-508$ & Arici and Bat (2017) \\
\hline
\end{tabular}


This study showed that sedimentary concentrations of $\mathrm{Hg}$ and $\mathrm{Cd}$ collected in winter were generally higher than those of collected in spring, summer and autumn (Figure 3). In contrast, concentrations of $\mathrm{Pb}$ reached the highest levels in summer, but the lowest value occurred in winter. On the other hand, higher levels of $\mathrm{Cu}$ and $\mathrm{Zn}$ were found in spring and autumn. The seasonal variations were thought to be related to the hydrological parameters of the ecosystem. Distribution of heavy metals in sediments also depends on sets of conditions including wast inputs, sediment particle sizes and organic contents. It is well known that sediments contain more mud and higher values of organic content contain high metals enrichment. On the other hand, the heavy metal concentrations in sediments increased with decreasing the particle size in sediments (Bryan and Langston, 1992; Langston and Spence, 1994).

In this study, however, the difference among the seasons in metal content in sediments was not significant $(\mathrm{P}>0.05)$. $\mathrm{Zn}$ was found to be the highest and $\mathrm{Cd}$ was the lowest.

Sediment quality guideline values (SQGV) are one of the most important and useful tools to save and assay marine ecosystem from adverse effects. The results compared to those determined by the recommended SQGV (Simpson and Batley, 2016). In this study, the results were compared with SQGV to see data on the metal levels in sediments of Karakum shores of Sinop Peninsula. The levels of the metals were much lower than the amounts pointed out the sediment quality. SQGV and SQGV-high for $\mathrm{Hg}, \mathrm{Cd}, \mathrm{Pb}, \mathrm{Cu}$ and $\mathrm{Zn}$ are 0.15-1.0, 1.5-10, 50-220, 65-270 and 200-410 mg/kg dry wt., respectively (Simpson and Batley, 2016).

Comparing the heavy metals levels in sediments of this study with previous studies in the Black Sea coasts (Table 5), the metals levels in Karakum shores were generally lower than those obtained by different studies.

Zn showed the highest concentration in all species followed by $\mathrm{Cu}$, while non-essential metals showed the lower concentration. It is well known that many marine species concentrate certain transition elements such as $\mathrm{Zn}$ and $\mathrm{Cu}$. Since $\mathrm{Zn}$ and $\mathrm{Cu}$ are essential metals mainly with regard to many enzymatic reactions, it is possible that the uptake of these metals is associated with metabolic activity. In this study, the results demonstrate that the heavy metal levels in $C$. capitata were much higher than those in other species $(\mathrm{P}<0.05)$.

The differences in the accumulation of heavy metals in the Polychaetes species may be due to their different dietary habits and habitats. This type of feeding behavior would provide the most probable pathway for the entrance of particulate inorganic material. $C$. capitata prefers in fine sand to mud and feeds on microorganisms and detritus and sometimes occurs in large numbers in areas of organic enrichment (Barnes, 1994; Fish and Fish, 1996). P. cuftrifera feeds mainly on algae and diatoms. Length of life is believed to be three years. $P$. dumerilii lives in a mucous or membranous tube on the lower shore in rock crevices and also in shallow water on drifting seaweed. It feeds mainly on seaweed and associated microorganisms. $N$. zonata is omnivore and found at low water in sand and under stones.

Statistically significant differences were also noted between seasons. There appeared to be a general trend of increasing concentration in summer for the metals. The lowest accumulation in animals was seen for $\mathrm{Cd}$ and $\mathrm{Hg}$. The distribution of $\mathrm{Hg}$ through the environment is very complicated by the fact that $\mathrm{Hg}$ compounds are extremely volatile and for this reason distribution by atmospheric transport is important (Bat and Özkan, 2015). Hg binds most strongly with particulate organic material and with clay. Metal intake from sediment may be present during ingestion of organic substances as food, whereas uptake of metals from seawater may take place across the whole body surface. Contaminated sediment is likely to be an important source of metal uptake for benthic organisms especially polychaetes.

Comparing accumulation of metals in Polychaete species in this study with other studies in the Black Sea (Table 6), it can be seen that Waring et al. (2006) recorded higher concentrations of $\mathrm{Hg}$ and $\mathrm{Cd}$ in Australonuphis parateres of Australia coasts, whereas Dora et al. (2007) recorded higher $\mathrm{Pb}$ concentrations in Hediste diversicolor from Homa Lagoon-Turkey. High $\mathrm{Cu}$ values were for in Melinna palmata from Bulgaria coasts (Andreev et al., 1994) and high $\mathrm{Zn}$ values were recorded in Perinereis cultrifera from Venetian lagoonItaly (Volpi Ghirardini et al., 1999). Our values of these metals were lower than those in other studies (Table $6)$.

\section{CONCLUSION}

Concentration of $\mathrm{Hg}, \mathrm{Cd}, \mathrm{Pb}, \mathrm{Cu}$ and $\mathrm{Zn}$ in water, sediment as well as their existence in Polychaetes were appraised in this study. The amount of heavy metals in the sediment is much higher than that of water, because the sediments serve as reservoir for pollutants and dead organic matter sinking from the water column (Bat and Özkan, 2015).

As a result, raised metal amounts in sediments likely express the long-term deposition of these metals through atmospheric deposition, rivers and surface water runoff into the coasts, whereas water metals likely express short-term conditions. Although there is no industrial activity in Karakum, the uncontrolled discharge of untreated sewage, touristic and fishing wastes is the cause for accumulating these pollutants 
at the sediments. However, heavy metal levels in sediment samples were much lower values than the sediment quality guidelines.

The studied species are not consumed by people, so there is no guideline, but these species are good prey items for many high trophic levels in the food chains. In addition, metal levels do not exceed the molluscs and crustaceans standards.
In conclusion, the heavy metal concentrations which occurred in Karakum shores of Sinop Peninsula in the Black Sea could be attributed to sewage and waste discharged from the city of Sinop and touristic and fishing activities. The results of this study support that C. capitata is apt to accumulate most metals at levels comparable to other Polychaete species studied, and serves as a good bio-indicator organism (Dean, 2008; Jones and Kaly, 1996).

Table 5. Comparison of heavy metals concentration ( $\mu \mathrm{g} / \mathrm{g}$ dry wt.) in sediments of the Black Sea with previous studies.

\begin{tabular}{|c|c|c|c|c|c|c|}
\hline \multirow{2}{*}{ Region } & \multicolumn{5}{|l|}{ Metals } & \multirow{2}{*}{ References } \\
\hline & $\mathrm{Hg}$ & $\mathrm{Cd}$ & $\mathrm{Pb}$ & $\mathrm{Cu}$ & $\mathrm{Zn}$ & \\
\hline Sinop & $0.05-0.40$ & - & $3.06-3.77$ & $0.08-0.42$ & - & \multirow{3}{*}{ Ünsal et al. (1995) } \\
\hline Kızılırmak & $0.86-4.0$ & - & $6.22-11.32$ & $11.80-356.56$ & - & \\
\hline Yeşilırmak & $0.29-2.02$ & - & $38.74 \pm 39.5$ & $528.12 \pm 357.0$ & - & \\
\hline İğneada & - & $<0.02$ & $<0.05$ & $13.57 \pm 0.08$ & $119.3 \pm 0.7$ & \multirow{6}{*}{ Topcuoğlu et al. (2002) } \\
\hline Kilyos & - & $<0.02$ & $<0.05$ & $4.00 \pm 0.02$ & $33.9 \pm 0.1$ & \\
\hline Amasra & - & $0.73 \pm 0.08$ & $21.4 \pm 5.6$ & $27.60 \pm 0.24$ & $92.6 \pm 0.37$ & \\
\hline Sinop & - & $0.89 \pm 0.11$ & $15.1 \pm 2.9$ & $37.3 \pm 0.14$ & $91.5 \pm 0.45$ & \\
\hline Perşembe & - & $0.93 \pm 0.04$ & $31.1 \pm 2.0$ & $69.9 \pm 0.20$ & $82.9 \pm 0.16$ & \\
\hline Rize & - & $<0.02$ & $<0.05$ & $95.5 \pm 0.19$ & $267.4 \pm 0.26$ & \\
\hline Pazar & - & $<0.02$ & $<0.5$ & $15.5 \pm 0.5$ & $50.1 \pm 0.4$ & \multirow{2}{*}{ Topcuoğlu et al. (2003) } \\
\hline Rize & - & $<0.02$ & $39.2 \pm 4.3$ & $506.5 \pm 1.5$ & $484.2 \pm 1.1$ & \\
\hline Samsun & - & $<0.02$ & $12.13-223.7$ & 32.9-64.85 & $109.55-261.65$ & Bakan and Özkoç (2007) \\
\hline Yeşilirmak outer & - & $<0.02$ & $<0.01$ & $59.9 \pm 1.0$ & 325.3 & \multirow{4}{*}{ Balkıs et al. (2007) } \\
\hline Yeşilırmak inner & - & $<0.02$ & $<0.01$ & $43.7 \pm 2.1$ & 119.8 & \\
\hline Kızılırmak outer & - & $<0.02$ & $<0.01$ & $23.0 \pm 0.3$ & $91.4 \pm 0.5$ & \\
\hline Kızılırmak inner & - & $<0.02$ & $<0.01$ & $27.6 \pm 0.7$ & 119.5 & \\
\hline Yomra detritus & - & $\begin{array}{l}0.23 \pm 0.09 \\
1.20 \pm 0.05 \\
\end{array}$ & $\begin{array}{l}8.88 \pm 0.07 \\
47.11 \pm 2.12 \\
\end{array}$ & $\begin{array}{l}16.08 \pm 0.17 \\
60.03 \pm 0.68 \\
\end{array}$ & $\begin{array}{l}133 \pm 13 \\
175 \pm 18\end{array}$ & \multirow{4}{*}{ Ergül et al. (2008) } \\
\hline Yomra $(0-2 \mathrm{~cm})$ & - & $<0.02$ & $<0.1$ & $56.86 \pm 0.34$ & $182 \pm 17$ & \\
\hline Yomra $(0-8 \mathrm{~cm})$ & - & $<0.02$ & $<0.1$ & $52.03 \pm 0.61$ & $169 \pm 16$ & \\
\hline Yomra & - & $10.89-12.96$ & $230.2-2438.7$ & $416.79-3182.65$ & $1639.8-7495.9$ & \\
\hline $\begin{array}{lr}\text { Sakarya, } & \text { Yenice, } \\
\text { Kızllırmak, Yeşilırmak }\end{array}$ & - & 0.38 & 26 & 66 & 146 & $\begin{array}{l}\text { Yiğiterhan and Murray } \\
(2008)\end{array}$ \\
\hline Zonguldak coast & - & $0.13-0.81$ & $28-50$ & $21-39$ & $66-103$ & Coban et al. (2009) \\
\hline Trabzon-east & - & - & $12.34-83.78$ & 13.68-315.99 & $56.5-286.3$ & \multirow{2}{*}{ Özşeker and Erüz (2011) } \\
\hline Trabzon`west & - & - & $7.8-48.1$ & $31.68-86.24$ & $47.6-118.6$ & \\
\hline Rize Harbor & $0.01-0.07$ & $0.1-1.4$ & $16-33$ & $34-279$ & $82-383$ & Gedik and Boran (2013) \\
\hline Sakarya Canyon & - & $1.4-5.8$ & $5.1-25$ & $5.1-18$ & $43-286$ & Yalcin et al. (2013) \\
\hline Sinop & $0.06-0.08$ & $0.03-0.07$ & $5.8-6.9$ & $6.9-7.6$ & $15-23$ & Bat et al. (2015) \\
\hline Thrace & bdl-0.06 & $0.07-0.35$ & $0.86-16$ & - & - & $\begin{array}{l}\begin{array}{l}\text { Mulayim and Balkis } \\
(2015)\end{array} \\
\end{array}$ \\
\hline Çayeli & - & $0.2-0.5$ & $23-31$ & $36-67$ & $78-130$ & \multirow{6}{*}{ Alkan et al. (2015) } \\
\hline Rize & - & $0.3-0.5$ & 14-19 & $33-54$ & $78-96$ & \\
\hline Of & - & $0.2-0.3$ & 17-31 & $24-35$ & $50-70$ & \\
\hline Sürmene & - & $0.5-2.1$ & $26-158$ & 70-2334 & $87-1828$ & \\
\hline Arsin & - & $0.3-0.4$ & $30-48$ & $35-42$ & $73-87$ & \\
\hline Yomra & - & $0.3-0.4$ & $20-32$ & $22-40$ & $65-82$ & \\
\hline Yağlıdere Stream & - & $0.09-0.23$ & $9.6-21$ & $11-51$ & - & $\begin{array}{lll}\begin{array}{l}\text { Uncumusaoglu et } \\
(2016)\end{array} & \text { al. } \\
\end{array}$ \\
\hline Sinop & $<0.01-0.15$ & $0.05-0.17$ & $5.08-27.61$ & $5.21-52.42$ & $18.6-66.7$ & Bat et al. (2017) \\
\hline Karakum & 0.008 & 0.006 & 0.28 & 3.03 & 8.14 & This study \\
\hline
\end{tabular}


Table 6. Comparison of heavy metals concentrations in Polychaeta species with previous studies in the Black Sea and other seas.

\begin{tabular}{|c|c|c|c|c|c|c|c|}
\hline \multirow{2}{*}{ Species } & \multirow{2}{*}{ Location } & \multicolumn{5}{|l|}{ Metals } & \multirow{2}{*}{ References } \\
\hline & & $\mathrm{Hg}$ & $\mathrm{Cd}$ & $\mathrm{Pb}$ & $\mathrm{Cu}$ & $\mathrm{Zn}$ & \\
\hline Capitella capitata & \multirow{4}{*}{$\begin{array}{l}\text { Karakum shores of } \\
\text { Sinop Peninsula- } \\
\text { BB } \\
\text { (dry wt.) }\end{array}$} & $0.087-0.092$ & $0.066-0.081$ & $1.2-1.5$ & $5.69-7.23$ & $18-21$ & \multirow{4}{*}{ This study } \\
\hline Nereis zonata & & $0.058-0.062$ & $0.037-0.052$ & $0.66-0.75$ & $2.75-4.21$ & $6-9$ & \\
\hline $\begin{array}{l}\text { Platynereis } \\
\text { dumerilii }\end{array}$ & & $0.068-0.072$ & $0.048-0.065$ & $0.89-0.95$ & $4.11-5.34$ & $9-12$ & \\
\hline $\begin{array}{l}\text { Perinereis } \\
\text { cultrifera }\end{array}$ & & $0.038-0.051$ & $0.042-0.061$ & $0.82-0.90$ & $5.55-6.88$ & $11-16$ & \\
\hline Ophelia bicornis & $\begin{array}{l}\text { Sinop-BS } \\
\text { (wet wt.) }\end{array}$ & $0.023-0.031$ & $0.055-0.071$ & $0.39-0.67$ & $9.87-13.6$ & $24-37$ & Bat et al. (2016) \\
\hline Nereis diversicolor & $\begin{array}{l}\text { Sinop-BS } \\
\text { (dry wt.) }\end{array}$ & $0.025-0.089$ & $0.047-0.082$ & $0.52-0.94$ & - & - & Bat et al. (2018) \\
\hline Melinna palmata & \multirow{3}{*}{$\begin{array}{l}\text { Bulgaria-BS } \\
\text { (dry wt.) }\end{array}$} & - & 2.50 & 9.12 & 222 & 143 & \multirow{3}{*}{$\begin{array}{l}\text { Andreev } \\
(1994)\end{array}$} \\
\hline Nephtys cirrosa & & - & 1.51 & 3.93 & 88 & 349 & \\
\hline Terebelides stroemi & & - & 2.55 & 7.68 & 64 & 159 & \\
\hline Hediste diversicolor & $\begin{array}{l}\text { Homa Lagoon- } \\
\text { Turkey (wet wt.) }\end{array}$ & - & 0.05 & 10.15 & 3.98 & - & Dora et al. (2007) \\
\hline $\begin{array}{l}\text { Oncholamium } \\
\text { ramosum }\end{array}$ & \multirow{6}{*}{$\begin{array}{l}\text { Zolotoi Rog Bay } \\
\text {-Sea of Japan } \\
\text { (wet wt.) }\end{array}$} & - & $0.96 \pm 0.08$ & - & $17.3 \pm 0.3$ & $217.0 \pm 6.50$ & \multirow{7}{*}{$\begin{array}{l}\text { Davydkova et al. } \\
(2005)\end{array}$} \\
\hline Ophryotrocha sp. & & - & $0.30 \pm 0.02$ & - & $3.1 \pm 0.10$ & $24.4 \pm 0.73$ & \\
\hline Nereis vexillosa & & - & $0.33 \pm 0.03$ & - & $1.3 \pm 0.25$ & $44.5 \pm 1.30$ & \\
\hline Alitta brandti & & - & $0.26 \pm 0.02$ & - & $1.8 \pm 0.04$ & $28.2 \pm 0.80$ & \\
\hline Capitella capitata & & - & $0.30 \pm 0.02$ & - & $1.4 \pm 0.03$ & $30.3 \pm 0.90$ & \\
\hline $\begin{array}{l}\text { Dorvillea } \\
\text { (Schistomeringos) } \\
\text { japonica } \\
\end{array}$ & & - & $0.49 \pm 0.04$ & - & $3.5 \pm 0.07$ & $32.7 \pm 0.96$ & \\
\hline $\begin{array}{l}\text { Dorvillea } \\
\text { (Schistomeringos) } \\
\text { japonica }\end{array}$ & $\begin{array}{l}\text { Vostok Bay- Sea of } \\
\text { Japan } \\
\text { (wet wt.) }\end{array}$ & - & Not found & - & $0.96 \pm 0.02$ & Not found & \\
\hline Hediste diversicolor & \multirow{3}{*}{$\begin{array}{l}\text { Venetian lagoon- } \\
\text { Italy (dry wt.) }\end{array}$} & - & $0.035-0.550$ & - & - & $177-358$ & \multirow{3}{*}{$\begin{array}{l}\text { Volpi Ghirardini } \\
\text { et al. (1999) }\end{array}$} \\
\hline Neanthes succinea & & - & $0.084-0.808$ & - & - & $242-477$ & \\
\hline $\begin{array}{l}\text { Perinereis } \\
\text { cultrifera }\end{array}$ & & - & $0.110-0.970$ & - & - & $177-518$ & \\
\hline $\begin{array}{l}\text { Australonuphis } \\
\text { parateres }\end{array}$ & \multirow{8}{*}{$\begin{array}{l}\text { Australia } \\
\text { (dry wt.) }\end{array}$} & $0.22 \pm 0.12$ & $17 \pm 10$ & $1.9 \pm 0.6$ & $8.1 \pm 2.9$ & $195 \pm 62$ & \multirow{8}{*}{$\begin{array}{l}\text { Waring et al. } \\
(2006)\end{array}$} \\
\hline $\begin{array}{l}\text { Galeolaria } \\
\text { caespitosa }\end{array}$ & & $0.8 \pm 0.88$ & $8.2 \pm 1.1$ & $1.2 \pm 0.5$ & $9.7 \pm 4.9$ & $225 \pm 49$ & \\
\hline Marphysa sp. & & $0.13 \pm 0.1$ & $0.2 \pm 0.11$ & $3.2 \pm 3.2$ & $26 \pm 14$ & $75 \pm 22$ & \\
\hline $\begin{array}{l}\text { Notomastus } \\
\text { estuarius }\end{array}$ & & $0.88 \pm 0.75$ & $0.07 \pm 0.02$ & $2.5 \pm 0.9$ & $13.3 \pm 1.3$ & $62 \pm 7$ & \\
\hline $\begin{array}{l}\text { Australonereis } \\
\text { ehlersi }\end{array}$ & & $0.13 \pm 0.1$ & $0.47 \pm 0.73$ & $0.09 \pm 0.07$ & $6.3 \pm 1.4$ & $92 \pm 16$ & \\
\hline Sigalion sp. & & $0.13 \pm 0.08$ & $0.48 \pm 0.23$ & $0.36 \pm 0.17$ & $9.3 \pm 5.2$ & $124 \pm 49$ & \\
\hline Lumbrinereis sp. & & $0.08 \pm 0.09$ & $0.29 \pm 0.02$ & $0.4 \pm 0.29$ & $3.4 \pm 0.5$ & $47 \pm 7$ & \\
\hline Scoloplos simplex & & $0.22 \pm 0.24$ & $0.36 \pm 0.17$ & $0.58 \pm 0.18$ & $9 \pm 3.8$ & $78 \pm 18$ & \\
\hline
\end{tabular}

\section{ACKNOWLEDGEMENT}

The authors wish to thank the Department of Hydrobiology, Fisheries Faculty, University of Sinop for providing laboratory facilities during the study.

\section{REFERENCES}

Alkan N, Alkan A, Akbas U, Fisher A 2015. Metal pollution assessment in sediments of the southeastern Black Sea Coast of Turkey. Soil Sediment Contam.: An Int. J., 24(3): 290-305.

Andreev G, Simeonov V, Stoikov S 1994. Occurrence and distribution of heavy metals in benthic organisms from the black sea, Toxicological \& Environmental Chemistry, 45(3-4): 167-171.

Arici E, Bat L 2017. Assessment of elemental uptakes by Ulva (Chlorophyta) species collected from Sinop coasts of the Black Sea. Pakistan Journal of Marine Sciences, 26(1-2): 01-13.

Bakan G, Özkoç HB 2007. An ecological risk assessment of the impact of heavy metals in surface sediments on biota from the mid-Black Sea coast of Turkey. International Journal of Environmental Studies. 64: 45-57.

Balkıs N, Topcuoğlu S, Güven KC, Öztürk B, Topaloğlu 
B, Kırbaşoğlu C, Aksu A 2007. Heavy metals in shallow sediments from the Black Sea, Marmara Sea and Aegean Sea regions of Turkey. J. Black Sea/Medit. Environ., 13: 147-153.

Barnes RSK 1994. The brackish-water fauna of northwestern Europe. Cambridge University Press, Great Britain pp. 287.

Bat L, Arici E 2018. Chapter 5. Heavy Metal Levels in Fish, Molluscs, and Crustacea From Turkish Seas and Potential Risk of Human Health. In: Holban AM, Grumezescu AM. (Eds.) Handbook of Food Bioengineering, Volume 13, Food Quality: Balancing Health and Disease. Elsevier, Academic Press, ISBN: 978-0-12-811442-1, 159-196pp.

Bat L, Gökkurt O, Sezgin M, Üstün F, Sahin F 2009. Evaluation of the Black Sea land based sources of pollution the coastal region of Turkey. The Open Marine Biology Journal, 3: 112-124.

Bat L, Özkan EY 2015. Chapter 13. Heavy metal levels in sediment of the Turkish Black Sea coast. In: Bikarska I, Raykov V, Nikolov N. (Eds.) Progressive Engineering Practices in Marine Resource Management. IGI Global book series Advances in Environmental Engineering and Green Technologies (AEEGT) (ISSN: 2326-9162; eISSN: 2326-9170) USA, 399-419 pp.

Bat L, Özkan EY, Öztekin HC 2015. The contamination status of trace metals in Sinop coast of the Black Sea, Turkey. Caspian Journal of Environmental Sciences, 13 (1): 1-10.

Bat L, Arici E, Öztekin A, Yardim Ö 2016. A preliminary study of the heavy metal levels in Ophelia bicornis (Savigny, 1820) in the Black Sea. Pakistan Journal of Marine Sciences, 25 (1-2): 93100.

Bat L, Öztekin A, Şahin F, Arıcı E, Özsandıkçı U 2018. An overview of the Black Sea pollution in Turkey. MedFAR., 1(2): 67-86.

Bat L, Sezgin M, Satılmış HH, Şahin F, Üstün F, Birinci-Özdemir Z, Gökkurt-Baki O 2011. Biological diversity of the Turkish Black Sea coast. Turkish Journal of Fisheries and Aquatic Sciences, 11: 683692.

Bat L 2005. A review of sediment toxicity bioassays using the amphipods and polychaetes. Turkish Journal of Fisheries and Aquatic Sciences, 5:119139.

Bat L 2017. The Contamination Status of Heavy Metals in Fish from the Black Sea, Turkey and Potential Risks to Human Health. In: Sezgin M, Bat L, Ürkmez D, Arıcı E, Öztürk B (Eds.) Black Sea Marine Environment: The Turkish Shelf. Turkish Marine Research Foundation (TUDAV), Publication No: 46, ISBN- 978-975-8825-38-7, Istanbul, TURKEY, 322-418 pp.

Bat L, Şahin F, Öztekin A 2018. Toxic Metals in Nereis diversicolor Müller, 1776 from Inner Shores in Sinop Peninsula of the Black Sea as Bio-Indicator
Species. Pakistan Journal of Marine Sciences, 27(1): 11-20.

Bryan GW, Langston WJ 1992. Bioavailability, accumulation and effects of heavy metals in sediments with special reference to United Kingdom estuaries: a review. Environmental Pollution, 76: 89-131.

Buchanan JB 1984. Sediment analysis. In: N.A. Holme and A.D. McIntyre (Eds.), Methods for the Study of Marine Benthos. Blackwell Sci. Publ., pp. 41-65.

Cevik U, Damla N, Kobya AI, Bulut VN, Duran C, Dalgic G, Bozacı R 2008. Assessment of metal element concentrations in mussel ( $M$. galloprovincialis) in Eastern Black Sea, Turkey. Journal of Hazardous Materials, 160(2-3):396-401.

Coban B. Balkıs N, Aksu A 2009. Heavy metal levels in sea water and sediments of Zonguldak, Turkey. Journal of Black Sea/Mediterranean Environment, 15(1): 23-32.

Davydkova IL, Fadeeva NP, Kovekovdova LT, Fadeev VI 2005. Heavy metal contents in tissues of dominant species of the benthos and in bottom sediments of Zolotoi Rog Bay, Sea of Japan. Russian Journal of Marine Biology, 31(3): 176-180.

Dean HK 2008. The use of polychaetes (Annelida) as indicator species of marine pollution: a review. Revista de Biología Tropical, 56(4): 11-38.

Dora EÇ, Sunlu U, Ergen Z 2007. Heavy metal concentrations in Hediste diversicolor (Polychaeta) and sediments from Homa Lagoon (Izmir BayTurkey). In CIESM 38th meeting (Vol. 253).

Ergül HA, Topcuoğlu S, Ölmez E, Kırbaşoğlu Ç 2008. Heavy metals in sinking particles and bottom sediments from the eastern Turkish coast of the Black Sea. Estuar. Coast. Shelf S., 78(2): 396-402.

Fish JD, Fish S 1996. A student's guide to the seashore. Second edition. Cambridge University Press, Great Britain pp. 564.

Gedik K, Boran M 2013. Assessment of metal accumulation and ecological risk around Rize Harbor, Turkey (southeast Black Sea) affected by copper ore loading operations by using different sediment indexes. Bulletin of Environmental Contamination and Toxicology, 90(2): 176-181.

Jones GP, Kaly UL 1996. Chapter 3. Criteria for selecting marine organisms in biomonitoring studies. In: Schmitt RJ, Osenberg CW. (Eds). Detecting Ecological Impacts Concepts and Applications in Coastal Habitats. Academic Press, 29-48 pp. doi:10.1016/b978-012627255-0/50005-7

Langston WJ, Spence SK 1994. Metal analysis. In: P. Calow (Ed.), Handbook of Ecotoxicology. Oxford Blackwell Sci. Publ., London. Vol. 2, Ch. 4, 45-78.

Mulayim A, Balkıs H 2015. Toxic metal (Pb,Cd,Cr, Hg) levels in Rapana venosa (Valenciennes, 1846), Eriphia verrucosa (Forskal, 1775) and sediment samples from the Black Sea littoral (Thrace, Turkey). Mar. Pollut. Bull., 95: 215-222. 
Noreña RDA, Arenas TAM, Murillo PE, Guío DAJ, Méndez AJJ 2012. Heavy metals (Cd, Pband Ni) in fish species commercially important from Magdalena river, Tolima tract, Colombia Revista Tumbaga, 7: 51-76.

Özşeker K, Erüz C 2011. Heavy metal (Ni, Cu, Pb, Zn) distribution in sediments from Trabzon in the Black Sea. Indian Journal of Geo-Marine Sciences, 40: 4854.

Simpson SL, Batley GE 2016, Sediment quality assessment: a practical guide, Second Edition, CSIRO Publishing Australia

Topcuoğlu S, Kırbaşoğlu C, Güngör N 2002. Heavy metals in organisms and sediments from Turkish Coast of the Black Sea, 1997-1998. Environ. Int., 27: 521-526.

Topcuoğlu S, Ergül HA, Baysal A, Ölmez E, Kut D 2003. Determination of radionuclide and heavy metal concentrations in biota and sediment samples from Pazar and Rize stations in the Eastern Black Sea. Fresenius Environmental Bulletin, 12: 695699.

Turkish Environmental Regulations Water Pollution Control Regulation, 2004-2005. http://www.cevre orman._gov.tr/yasa/yonetmelik

Uncumusaoglu A, Umit S, Akkan T 2016. Environmental Contamination of Heavy metals in the Yaglidere Stream (Giresun), southeastern Black Sea. Fresenius Environmental Bulletin, 25(12): 5492-5498.

Ünsal M, Bekiroğlu Y, Beşiktepe (Akdoğan) Ş, Kayıkçı
Y, Alemdağ Y, Aktaş M, Yıldırım C 1995. Determination of the land-based sources of heavy pollution in the middle and eastern Black Sea Coast Tarım ve Köyişleri Bakanlığı Trabzon Su Ürünleri Araştırma Enstitüsü. Project No: DEBAG-121/G; pp: 59 (in Turkish).

Volpi Ghirardini A, Cavallini L, Delaney E, Tagliapietra D, Ghetti PF, Bettiol C, Argese E 1999. $H$. diversicolor, $N$. succinea and $P$. cultrifera (Polychaeta: Nereididae) as bioaccumulators of cadmium and zinc from sediments: preliminary results in the Venetian lagoon (Italy). Toxicological \& Environmental Chemistry, 71(3-4): 457-474.

Waring JS, Maher WA, Krikowa F 2006. Trace metal bioaccumulation in eight common coastal Australian polychaeta. Journal of Environmental Monitoring, 8(11):1149. doi:10.1039/b612509n

Wentworth CK 1922. A Scale of Grade and Class Terms for Clastic Sediments, Journal of Geology, Vol. 30, No. 5, pp. 377-392. doi:10.1086/622910

Yalcin MG, Simsek G, Ocak SB, Yalcin F, Kalayci Y, Karaman ME 2013. Multivariate statistics and heavy metals contamination in beach sediments from the Sakarya Canyon, Turkey. Asian Journal of Chemistry, 25(4): 2059-2066.

Yiğiterhan O, Murray JW 2008. Trace metal composition of particulate matter of the Danube River and Turkish rivers draining into the Black Sea. Marine Chemistry, 111: 63-76.

Zar JH 1984. Biostatistical analysis. Prentice Hall, Int, New Jersey, 718. 